\section{PSICOLOGIA IBEROAMERICANA}

\section{Psicología lberoamericana}

ISSN: 1405-0943

psicología.iberoamericana@uia.mx

Universidad Iberoamericana, Ciudad de

México

México

Rojas García, Adelaida; Rocha Reza, Sonia; Serrano Barquín, Carolina; Bárcenas Jaimez, Gustavo Validity and Reliability of the Scale of Attitudes toward Artisanal Production

Psicología Iberoamericana, vol. 18, núm. 2, julio-diciembre, 2010, pp. 66-74

Universidad Iberoamericana, Ciudad de México

Distrito Federal, México

Available in: http://www.redalyc.org/articulo.oa?id=133915921008

How to cite

Complete issue

More information about this article

Journal's homepage in redalyc.org

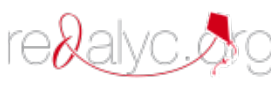

Scientific Information System Network of Scientific Journals from Latin America, the Caribbean, Spain and Portugal Non-profit academic project, developed under the open access initiative 


\title{
Validity and Reliability of the Scale of Attitudes toward Artisanal Production
}

\author{
Validez y Confiabilidad de la Escala de Actitiudes hacia la Producción Artesanal
}

\author{
Adelaida Rojas García \\ Sonia Rocha Reza \\ Carolina Serrano Barquín \\ Facultad de Ciencias de la Conducta \\ Universidad Autónoma del Estado de México, México \\ Gustavo Bárcenas Jaimez* \\ Department of Counsiling and Higher Education \\ UNIVERSITY OF NORTH TEXAS
}

\section{RESUMEN}

El objetivo del presente trabajo fue obtener la validez y confiabilidad de la Escala de Actitudes hacia la Producción Artesanal, para lo cual se obtuvo una muestra integrada por 150 artesanos del Estado de México. Para la obtención de la validez y confiabilidad de dicho instrumento se llevó a cabo un análisis factorial con un método de rotación Varimax y se obtuvo el Alpha de Cronbach. Los resultados apuntan a una mayor carga factorial en el componente conductual de las actitudes, lo que señala que los artesanos tienden a actuar ante las diferentes situaciones, lo cual les ha permitido seguir preservando sus costumbres y tradiciones artesanales.

Descriptores: Confiabilidad, validez, actitudes, producción artesanal.

\section{ABSTRACT}

The object was to obtain the validity and reliability of the Scale of Attitudes towards Artisan Production, for which a sample was integrated by 150 craftsmen from the State of Mexico. For obtaining of the validity and reliability of this instrument, a factorial analysis with a method of Varimax rotation was carried out and then the Cronbach Alpha was obtained. The results show that the craftsmen tend to use more the conductual component of attitudes. This indicates that they prefer to act in order to face the different situations which have allowed them to continue preserving their artisan customs and traditions.

Key words: Reliability, validity, attitudes, artisanal production.

\footnotetext{
'Para correspondencia: Adelaida Rojas García. Doctora en Investigación Psicológica. Profesora-investigadora, Facultad de Ciencias de la Conducta de la Universidad Autónoma del Estado de México. Dirección: Privada fresnos\# 7 los cedros Metepec, rojasgarcia.adelaida@gmail.com Tel: 017222 720076. Sonia Rocha Reza. Doctora en Investigación Psicológica. Profesora-investigadora, Facultad de Ciencias de la Conducta de la Universidad Autónoma del Estado de México. Dirección: Priv. Rincón del parque \#127, Toluca México, sonia.2606@hotmail.com Tel: 017222782401 . Carolina Serrano Barquín. Doctora en Ciencias Sociales. Profesora-investigadora, Facultad de Ciencias de la Conducta de la Universidad Autónoma del Estado de México. Dirección: Aculco \#103, Toluca, México. carolinasb@hotmail.com Tel: 0172221327 93. Gustavo Bárcenas Jaimez. Estudiante de la Maestría en Psicología de la Facultad de Ciencias de la Conducta de la UAEMex, becado a la University of North Texas, Department of Counsiling and Higher Education. Dirección: 1201 Av. Apt. 5 Denton, Texas. 76201. barcenaz10@hotmail.com Tel: 9404429521.
} 
The artisan activity is comprised of the history of the man. Some of the most important functions have been the maintenance of cultural identity; therefore crafts are nothing but a reflection of the origins of man, their customs and traditions. On the other hand, also they fulfill an economic function, to sources of work and thereby allowing the livelihood of some communities since they provide economic resources.

In this way, it is necessary to define the concept of "crafts". Some authors such as Candini (1986) have shown how handicrafts are a manual activity which require a minimal intervention of machines. This means the tasks are carried out manually. In this way, each piece is unique and different from the others, and so can differentiate production in series. For some other authors, such as Peñaloza (1982), handicrafts basically include pieces and work made manually with little intervention of machinery. Usually they are a decorative or common object, which denotes their origin, the productive process and their usefulness. Accordingly, the person dedicated to this activity is a craftsman.

Unfortunately, there is not a national census (or State) about people who are dedicated to this activity. And due to this fact, it is complicated to demonstrate the importance that this sector has for the development of Mexico. The numbers that are provided by institutions and organizations vary between $8.5 \mathrm{mi}$ llion (SEDESOL; quoted by the Comisión de Fomento Industrial, Comercial y Cooperativismo, 2007) and 10 million of craftsmen in the country (Fondo Nacional para el Fomento de las Artesanías, quoted by El Financiero en línea, 2008).

Particularly in the State of Mexico, although there is no data about the number of artisans, a variety of handicrafts, which are considered as an expression of wisdom and imagination of the Mexiquenses artisans, can be appreciated. Examples of them are the textile work, pottery, ceramics, wood, vegetable fibers, glass, wax, etc. The Mexiquenses craftsmen tend to be recognized because of their great sensitivity and creativity (Secretaría de Turismo, 2008).

Therefore, handicrafts are part of an important role within the preservation of the culture of communities and towns. It also means the preservation of identity, customs, and traditions. Furthermore, crafts and agricultural work are intimately linked and play an important role in the economy of the State of Mexico (Novelo, 1996).

Nevertheless, in a globalized world, handicrafts are beginning to be displaced by products with a lower cost from industrial processes, which have a similar appearance but a lower quality (Peñaloza, 1982). Then, there is a double movement of comsumption. On one hand, the clothes and the objects from indigeniuos origin are increasingly less used in peasent societies as a result of the industrial items displacement. These items are cheaper, more attractive in their design and more modern. However, on the other hand, the decreasing artesanal production is reactivated thanks to the growing demand of exotic objects in cities of the same country or abroad (Candini, 1986). Nowadays, a clear example of this situation is the preferences by $\mathrm{pi}$ racy, especially the objects made in China, which compete not only with crafts from the State of Mexico but also with national handicrafts (El Financiero en línea, 2008).

Because of this reason, the study and measurement of attitudes is relevant to access the important elements, according to their properties and components, the feasibility that certain behaviors may occur in the future within the artisanal population and productions.

In this way, it is convenient to begin by defining an attitude, which has multiple definitions. However, one of the most known is the one that Allport supports (1935; quoted by Worchel, Cooper, Goethals \& Olson, 2003), who says that an attitude is a mental state or a neural predisposition, organized by the experience, which has a directive or dynamic influence on the response of the person to all objects and situations with which he or she is involved.

Rodrigues, Assmar \& Jablonski (2002) mention that attitude is a lasting organization of beliefs and cognitions in general. They are equipped with an affective load in favor or against a defined social object. Finally, we must summon Worchel et al. (2003) for whom an attitude is an evaluative trial (good or bad) of an object. Thus, an attitude represents the positive or negative propensity of the individual towards the attitudinal object. Therefore, he says, the attitudes are developed from cognitive, affective, or behavioral information. This means that the evaluations of the objects 
are based in knowledge and ideas on them (cognitive information), emotional reactions and feelings (emotional information), and the behavioral and previews answers (behavioral information).

In this way, attitudes revolve around three components: cognitive, affective, and behavioral (Rodrígues et al., 2002; Worchel et al., 2003).

\section{a) Cognitive component}

Within this component, perceptions and beliefs toward an object reflect the knowledge a person has about that object (Canto, 1994). There are two main categories of beliefs: the ones that are based on the direct personal experiences with the object, and the ones based in the indirect information obtained from other people (Worchel et al., 2003). As a consequence, not surprisingly, the attitudes based on the direct experiences predict in a better way the behavior. Thus, people tend to trust more in their own sensations rather than trust information given by others.

\section{b) Affective component}

It refers to the emotions and feelings associated with a particular object and whether it is experienced as pleasant or unpleasant (Zajonc, 1980; quoted by Worchel et al., 2003) the affective or evaluative responses are more primitive that those that are related with cognition. In an evolutionary way, the affective reactions are earlier or more basic than the cognitive ones. Zajonc states that basic emotional responses (pleasant or unpleasant) may occur before the individual is aware of the object (before categorization and recognition).

\section{c) Behavioral component}

This component involves a tendency to react toward the objects in a certain way. Canto (1994) indicates that this is the active component of the attitude; in other words, it is the result of the cognitive and affective components. Nonetheless, sometimes there is a problem between the congruence of the cognitive and the affective components. That is because attitudes do not predict the prescribed behavior, because such behavior is not under control of will (Worchel et al., 2003). The attitudes (personal preferences) influence in behavior just when the individual chooses whether to perform the action or not.
Many factors make an act relatively involuntary (social standards are an example). A second factor influencing the congruence between attitudes and behavior is the nature of the last one. It is possible that certain behaviors are more consistent with the attitudes of individuals than others. Fishbein \& Ajzen (quoted by Worchel et al., 2003) argue that the subjective rules (such as social pressure) are as independent of the attitudes as determinants of the behavior. Therefore, if standards that affect conduct are very strong, the probabilities that attitudes influence the conduct are very low (the influence of the standards will be dominant).

Now, what are the functions of attitudes? Several authors have speculated about it. The best-known analysis is that of Katz and Kahn (1988) who identified four possible attitude functions. First, attitudes serve to maximize the rewards and minimize punishment, what he called utilitarian function. These authors point that attitudes which play an adaptive function can serve as a medium to achieve the desired goal, or to identify the experiences that previously led to the satisfaction of those goals.

Second, attitudes help observers to understand their environment providing short evaluations of objects and groups of objects. According to Katz and Kaha (1988), this is the function of knowledge.

Third, attitudes express sometimes the values and identity of individuals toward others. Katz and Kaha (1988) called this "expressive function of values". Through this function, the individual achieves the expression of values that he appreciates the most, with confirmation of the most positive aspects of his own concept. Finally, attitudes can serve to avoid painful truths. These authors called this function "the self defensive role". Underlying processes enable the individual to recognize his own deficiencies, which help him to preserve the concept that he has of himself. It is also important to mention that an important advance came from the Theory of the Reasoned Action of Fishben and Ajzen (quoted by Worchel et al., 2003). They explained how attitudes are based in cognitive beliefs. They argued that, since general attitudes just predict general behavior, and specific attitudes predict specific behavior, the measurement of attitudes and behavior must be compatible. This discussion about the compatibility of the measurement of attitudes and behavior 
turned out to be crucial for the understanding of the congruence between attitudes and behavior.

Because of this reason, it is necessary for us to measure attitudes in the field of psychology. Then, measure is, according to a certain group of standards, to assign a number to observations. If the phenomenon is the attitude, the process of measurement becomes more complex since attitudes cannot be directly observed but need to be inferred from the object of the conduct (Summers, 1984). In the same way, Ajzen (1989; quoted by Moreno, 1999) says that an attitude is not directly observable but is a latent variable which has to be inferred from different responses. It also reflects a global positive or negative evaluation of the object of the attitude.

Attitudes, therefore, can be measured asking people their evaluation of the object. For instance, people can be asked to score their agreement or disagreement about several statements which express evaluations of the objects (Likert, 1932; quoted by Worchel et al., 2003).

In the same way, it is relevant to mention that for the present paper the scale to use is the Likert scale. This scale is one of the most commonly used to measure attitudes. It is easy to develop and apply. Moreover, it has a good level of correlation with other scales and measurement criteria of attitudes (Rodrigues et al., 2002).

The Likert scale is a series of statements (usually between 20 and 30) which relate to an attitudinal object, so that half of them are favorable to the attitudinal object and the other half unfavorable to the object. The convenience of dividing the number of favorable and unfavorable statements comes from the need to avoid certain individual tendencies, such as the prevalence of agreement over disagreement. Each statement claims five options: totally agree, partially agree, not sure, partially in disagreement, and completely disagree. Each of these options is given a numerical value, from 1 to 5 . Who prepares the scale must determine in which way (positive or negative) they will attribute the highest values (Rodrigues et al., 2002).

Nevertheless, when a scale is constructed it is necessary to put it to under some degree of reliability and validity. The first is related to the degree of consistence between the different measurements of a variable, while the second one is the measurement in which a scale represents precisely the subject of interest (Hair, Anderson, Taham \& Black, 2004).

\section{METHODOLOGY}

The present paper aimed to obtain the validity and reliability of the Scale of Attitudes toward the Artisanal Production which was created for it. This scale was created in order to have an instrument which can measure such attitudes. To do this, the present study was carried out in some communities of the State of Mexico, such as Metepec, Antonio la Isla, San Andrés Cuexcontitlan, Temoaya, Toluca, etc. A total of 150 applications were done. The participants were craftsmen, both men and women among 20 and 60 years old with a predominant schooling of junior high school and just one bachelor's case. Most of them were full time craftsmen.

The sample used in each community was of intentional type. In this way, the election of participants does not depend on the probability that all of them can be chosen but the decision of a researcher or a group of them (Hernández Sampieri, Fernández-Collado \& Baptista Lucio, 2003). In this case, in order to obtain a sample from the artisanal population $(\mathrm{N}=150)$ of each community it had to fulfill with the following criteria:

- Craftsmen who had their own workroom.

- Craftsmen who made handicrafts from their own community.

The instrument used in this research was the Scale of Attitudes toward the Artisanal Production, which contains a series of statements in its affective, cognitive, and behavioral components. At first, the scale consisted of 27 reagents that were subdivided into different aspects such as elaboration, procedures, sales, etc. Each one has three different answer options: always, sometimes, or never. It was based on facilitating the craftsmen answers, and on what Hernandez et al. (2003) mention about the number of options. In the same way, according to such authors, it sought a balance between positive and negative reagents.

This Scale of Attitudes arises from the first stage of research that was made in 2004: Diagnostic on the Attitudes toward the Artisanal Population and types of 
Leadership in the community of Gudalupita, State of Mexico (Rojas \& Rocha, 2007). From this research, several questionnaires were made. One of them was the questionnaire named "Attitudes toward Artisanal production", which was the base to construct the instrument called "Evaluation of the Attitudes toward Artisanal production and commercialization". A frequency analysis was obtained in a data base from this last instrument, and then it was structured to construct the instrument, which in the end was judged for the researchers in charge and some experts.

Now, the procedure to obtain the research data was as follows:

- Visits were scheduled to the above-mentioned communities

- It was explained to the artisans what the research was about and the purpose of the instrument
- The instrument was applied individually

- The information was captured for the elaboration of the database through the statistical program SPSS-12

- The results were analyzed

- The results were codified

- Conclusions were obtained

- Finally, to achieve the validity and reliability of the instrument, a factorial analysis was carried out with a varimax rotation method, and then the Cronbach's alpha was obtained.

\section{RESULTS}

Chart 1 Reports the result of the factorial analysis and the Cronbach's alpha for each reagent, according also to the component of the attitude.

Table 1.1 Factorial Analysis and Cronbach's Alpha results. Also, the following list presents the variable, the name, and in parentheses a word with which it was tagged.

\begin{tabular}{|c|c|c|c|c|c|c|c|c|}
\hline \multicolumn{3}{|c|}{ COGNITION } & \multicolumn{3}{|c|}{ AFFECTION } & \multicolumn{3}{|c|}{ BEHAVIOR } \\
\hline Variable & $\begin{array}{l}\text { Factorial } \\
\text { Analysis }\end{array}$ & $\begin{array}{c}\text { Cron-bach's } \\
\text { Alpha }\end{array}$ & Variable & $\begin{array}{l}\text { Factorial } \\
\text { Analysis }\end{array}$ & $\begin{array}{c}\text { Cron-bach's } \\
\text { Alpha }\end{array}$ & Variable & $\begin{array}{l}\text { Factorial } \\
\text { Analysis }\end{array}$ & $\begin{array}{c}\text { Cron-bach's } \\
\text { Alpha }\end{array}$ \\
\hline $\begin{array}{l}\text { D1 } \\
\text { D4 } \\
\text { D5 }\end{array}$ & $\begin{array}{c}.82 \\
.87 \\
.87 \\
M=.85\end{array}$ & .83 & $\begin{array}{l}\text { A1 } \\
\text { A3 } \\
\text { A4 }\end{array}$ & $\begin{array}{c}.67 \\
.78 \\
.58 \\
M=.67\end{array}$ & .51 & $\begin{array}{l}\text { G3 } \\
\text { G4 } \\
\text { G5 }\end{array}$ & $\begin{array}{c}.62 \\
.77 \\
.61 \\
M=.66\end{array}$ & .57 \\
\hline $\begin{array}{l}\text { F1 } \\
\text { F4 } \\
\text { F7 }\end{array}$ & $\begin{array}{c}.74 \\
.79 \\
.70 \\
M=.74\end{array}$ & .74 & $\begin{array}{l}\mathrm{C} 1 \\
\mathrm{C} 2 \\
\mathrm{C} 3 \\
\mathrm{C} 4\end{array}$ & $\begin{array}{c}.75 \\
.80 \\
.71 \\
.84 \\
M=.70\end{array}$ & .78 & $\begin{array}{l}\text { O1 } \\
\text { O2 } \\
\text { O3 } \\
\text { O4 } \\
\text { O5 } \\
\text { O6 }\end{array}$ & $\begin{array}{c}.76 \\
.71 \\
.87 \\
.67 \\
.80 \\
.82 \\
M=.77\end{array}$ & .66 \\
\hline $\begin{array}{l}\text { K2 } \\
\text { K4 } \\
\text { K5 }\end{array}$ & $\begin{array}{c}.82 \\
.73 \\
.85 \\
M=.80\end{array}$ & .77 & $\begin{array}{l}\text { E1 } \\
\text { E3 } \\
\text { E4 } \\
\text { E5 }\end{array}$ & $\begin{array}{c}.73 \\
.76 \\
.86 \\
.89 \\
M=.81\end{array}$ & .85 & $\begin{array}{l}\text { P1 } \\
\text { P2 } \\
\text { P3 } \\
\text { P4 } \\
\text { P5 } \\
\text { P6 } \\
\text { P7 } \\
\text { P8 }\end{array}$ & $\begin{array}{c}.99 \\
.99 \\
.99 \\
.99 \\
.99 \\
.99 \\
.99 \\
.99 \\
M=.99\end{array}$ & 1.0 \\
\hline
\end{tabular}




\begin{tabular}{|c|c|c|c|c|c|c|c|c|}
\hline \multicolumn{3}{|c|}{ COGNITION } & \multicolumn{3}{|c|}{ AFFECTION } & \multicolumn{3}{|c|}{ BEHAVIOR } \\
\hline Variable & $\begin{array}{l}\text { Factorial } \\
\text { Analysis }\end{array}$ & $\begin{array}{l}\text { Cron-bach's } \\
\text { Alpha }\end{array}$ & Variable & $\begin{array}{l}\text { Factorial } \\
\text { Analysis }\end{array}$ & $\begin{array}{c}\text { Cron-bach's } \\
\text { Alpha }\end{array}$ & Variable & $\begin{array}{l}\text { Factorial } \\
\text { Analysis }\end{array}$ & $\begin{array}{l}\text { Cron-bach's } \\
\text { Alpha }\end{array}$ \\
\hline $\begin{array}{l}\text { M1 } \\
M 2 \\
M 3 \\
M 6\end{array}$ & $\begin{array}{c}.66 \\
.64 \\
.81 \\
.78 \\
M=.72\end{array}$ & .70 & & & & $\begin{array}{l}X 1 \\
\times 2 \\
X 3 \\
X 4 \\
x 5\end{array}$ & $\begin{array}{c}.99 \\
.99 \\
.99 \\
.99 \\
.99 \\
M=.99\end{array}$ & .99 \\
\hline $\begin{array}{l}\text { Q1 } \\
\text { Q3 } \\
\text { Q4 } \\
\text { Q5 }\end{array}$ & $\begin{array}{c}.84 \\
.66 \\
.85 \\
.76 \\
M=.77\end{array}$ & .80 & & & & & & \\
\hline $\begin{array}{l}\text { R2 } \\
\text { R4 } \\
\text { R5 }\end{array}$ & $\begin{array}{c}.62 \\
.73 \\
.80 \\
M=.71\end{array}$ & .49 & & & & & & \\
\hline $\begin{array}{l}\text { T1 } \\
\text { T2 } \\
\text { T3 }\end{array}$ & $\begin{array}{c}.99 \\
.99 \\
.99 \\
M=.99\end{array}$ & .99 & & & & & & \\
\hline $\begin{array}{l}\text { V1 } \\
\text { V2 } \\
\text { V3 } \\
\text { V4 }\end{array}$ & $\begin{array}{c}.99 \\
.99 \\
.99 \\
.99 \\
M=.99\end{array}$ & .99 & & & & & & \\
\hline $\begin{array}{l}\text { W1 } \\
\text { W2 } \\
\text { W3 }\end{array}$ & $\begin{array}{c}.99 \\
.99 \\
.99 \\
M=.99\end{array}$ & .99 & & & & & & \\
\hline $\begin{array}{l}\mathrm{Z} 1 \\
\mathrm{Z} 2 \\
\mathrm{Z3}\end{array}$ & $\begin{array}{c}.88 \\
.91 \\
.74 \\
M=.84\end{array}$ & .81 & & & & & & \\
\hline
\end{tabular}

Notice: Where each letter means: A. Identification with crafts (Identification). C. Feeling that causes to be a craftsman (Feeling).D. Crafts function (function). E. Feeling caused by the recognition of handicrafts abroad (Recognition). F. Function of the preservation of the artisanal traditions (Preservation). G. Characteristics of the production of handicrafts (Features). K. Remuneration of artisanal products (Remuneration). L. Artisanal production (Production). M. Transmission of craft knowledge (Transmission). $\mathrm{N}$. Young people facing the artisanal production (Young people). O. Artisan's children's opinion about the production of crafts (Artisan's children). P. Causes that origin the loss of the artisanal production (Artisanal loss). Q. Foreign products and artisans (Foreign products). R. Alternatives of promotion to the handicrafts (Promotion alternatives). T. Demand - supply. U. Causes which do not allow recovery of investment in crafts (Investment). V. Decrease in artisanal production (Reduction). W. Quantity and quality of artisanal production (Quantity and quality). X. Increase in sales of handicrafts (Increase in sales). Z. Opinion about the artisans' organizations (Artisans' Organization). 
The variable Identificación (A), relating to the emotional component and referring to the identification of the craftsman towards artisanal production, maintains three of its reagents with a factorial load of .67, .78, and .58 respectively, resulting a Cronbach's Alpha of .51 .

The variable Feeling $(C)$, corresponding to the affective component of attitudes, is referred by the feeling which causes the fact of being a craftsman. Four of its reagents are maintained with a factorial load of .75 , $.80, .71$, and .84 , the Cronbach's Alpha was of .78

About the variable Function (D), corresponding to the cognitive component, three of its reagents obtained a factorial load of .82, .87, and .87. Respectively, the Cronbach's Alpha was of .83

In the variable Recognition (E) four of its five reagents were maintained. This variable corresponds to the affective component and refers to the recognition that handicrafts have in different places. The reagents have a factorial load of $.73, .76, .86$, and .89 , and a Cronbach's Alpha of 85 .

The variable Preservation $(F)$ corresponds to the cognitive component which describes the reasons to preserve the artisanal activity. Three of its reagents were maintained with a factorial load of $.74, .79$, and .70 , obtaining a Cronbach's Alpha of .74

The variable Features $(G)$, corresponding to the behavioral component, describes the characteristics of artisanal production. It kept three out of seven of its original reagents. These reagents have a factorial load of .62, .77, and .61. It obtained a Cronbach's Alpha of .57

The variable Remuneration (K), which corresponds to the cognitive component, maintained six reagents. It refers to the remuneration of the artisanal activity. It is worth mentioning that the first three reagents obtained a factorial load of $.82, .73$, and .85 , while the rest obtained the factorial load in the second rotation. Then, the results are $.58, .82$, and .68 respectively. For the first group of reagents the Cronbach's load was of .77 , and for the second one .22

The variable Production (L), referred directly by the artisanal products and related to the cognitive component, maintained three out of five reagents. Its factorial load was of $.63, .69$, and .68 with a Cronbach's Alpha of .48.

The variable Transmission $(M)$ is related to the transmission of artisanal knowledge to the new gene- rations, and that corresponds to the cognitive component of attitudes. The factorial load of this reagent was obtained in four of them which correspond to $.66, .64$, .81 , and .78. On the other hand, Cronbach's Alpha was of .70

In the variable Young people $(N)$ were maintained its eight reagents. Three of them obtained a factorial load of $.82, .71$, and .82 . This variable is about what Young people think about the artisanal production, and it is related with the cognitive component.

The variable Artisan's kids (O) correspond to the attitude that the artisan's kids have toward the artisanal production. It maintained six reagents. This variable is related with the behavioral component. It was obtained a factorial load of $.76, .71, .87, .67, .80$, and .82 . Cronbach's Alpha was of .66

The variable Artisanal loss $(P)$ maintained its eight reagents. This variable refers to the Artisanal loss and is related with the behavioral component of attitudes. The factorial load was of .99 for the whole group, and a Cronbach's Alpha of 1.0

The variable Foreign products (Q) which corresponds to the cognitive component, relates foreign products in comparison with handicrafts. It maintains four out of eight reagents. It obtained a factorial load of .84, .66, .85, and .76, while Cronbach's Alpha was .80 What it refers to the variable Promotion Alternatives $(R)$ that maintained three reagents. This variable is related with the cognitive component of attitudes, and is about the possible alternatives to promote crafts. The obtained factorial loads were of .62, .73, and .80, and a Cronbach's Alpha of 49

The variable Demand-supply (T) maintained three reagents, which are related with the cognitive component. It is referred to the capacity of satisfying the demand of the artisanal products and shows a factorial load, in the whole group, of .99 with a Cronbach's Alpha of .99

In the variable Investment $(U)$ obtained a factorial load of .99 in the whole group and a Cronbach's Alpha of .99. This variable is related with the behavioral component of attitudes, and it describes the economical recovery to artisanal investment.

The variable Reduction (V) refers to the reduction of the artisanal production and it is related with the cognitive component of attitudes. It maintained 
four reagents which have a factorial load of .99 and a Cronbach's Alpha of 99

For the variable Quantity and Quality (W), we obtained a factorial load of .99, and a Cronbach's Alpha of .99 , too. It is related with the artisan's opinion about the quantity and quality of their products, and it corresponds to the cognitive component of attitudes.

The variable Increase in sales $(X)$ maintained its five reagents. This variable is related with the behavioral component, and it describes the convenience of using different ways for the sales. All of their reagents obtained factorial loads and a Cronbach's Alpha of .99 Finally, the variable Artisans' organizations $(Z)$ kept three out of 4 reagents. They obtained a factorial load of $.88, .91$, and .74 and a Cronbach's Alpha of .81. This variable is related with the behavioral component of attitudes and it describes the artisans' opinion about their organizations.

\section{DISCUSSION}

Based on the results of the implementation of the Scale of Attitudes towards the Artisanal Production, it can be said that this is a valid and reliable instrument. According to Hair et al. (2004), the criteria to select each factor is a factorial load of .45 forward. The factorial loads of .30 are considered in a low level, the ones with .40 are important, and the ones with .50 or higher are significant.

For this reason, the factorial loads that were obtained in the instrument are considered significant because they fluctuated between .50 and .99 it is important to highlight that the ones with the lowest factorial load were the ones related with the affective component.

On the other hand, the reliability of the instrument, as mentioned previously, was obtained through Cronbach's Alpha. Hair (2004) mentions that, the lowest limit for the Cronbach's alpha is of .70 and in some cases of .60. In the present paper it can be observed that most of the factors are within this rank. Nonetheless, it is important to mention that four of the factors are under .60: factor A with .51, factor $\mathrm{G}$ with .57 , factor $\mathrm{L}$ with .48 , and factor $\mathrm{R}$ with .49. The reliability and validity of the Scale of Attitudes toward the Artisanal Population shows that the people who participated in the research tended to give a variety of answers.
Basically, they gave ambiguous answers to the reagents related with the affective component of attitudes. As it can be observed, they were the reagents with the lowest factorial load. In this manner, this component is quoted by Worchel (2003) who says that, such affective responses occur before the individual is aware of the object. Therefore, the responses can be different from one individual to other, even though they are in the same situation.

In contrast, the component with the highest factorial load was the cognitive. This is not surprisingly because according to Canto (1994), in this component the beliefs and perceptions of an object (in this case the handicrafts) reflect the knowledge that a person has about that object. In this way, the rank based on direct personal experiences shows a clear knowledge from the artisans toward their own activity.

In this way, Canto (1994) says that, the behavioral component is the active component of the attitude, and although it had a higher load than the affective component, it was not similar to the cognitive component. It is because regularly there is a problem between the coherence of these components. It can be because of the artisans' need to behave in a certain way through the situations they face (such as the competence with foreign products).

Therefore, it is important for people their identity as artisans and, as a result, the preservation of handicrafts which is part of the local traditions in each community. So this tradition is maintained through the practice and commercialization of products. Thus, it is evident that just through reason and action, more than through affective mediums, artisans will achieve the maintenance of the traditions which have permitted them the livelihood through generations.

\section{CONCLUSION}

According to the results, the Scale of Attitudes towards the Artisanal Production is a valid and reliable instrument. It was obtained through a factorial analysis and Cronbach's Alpha. From this analysis, were obtained 20 valid reagents out of 27 , and from a total of 76 reagents.

Furthermore, the behavioral component is the one with a higher factorial load which indicates that artisans tend to react to situations presented rather than 
showing affection. This allows them to continue preserving their artisan tradition which in so many cases also is part of the family livelihood.

In short, this instrument provides aid to know what attitudes artisans take in the different situations they face. For this reason, it can be useful in comparative studies with different groups of craftsmen or artisan communities. So, this instrument is a valid and reliable instrument to be applied in populations who have the same criteria of the samples of this research.

\section{REFERENCES}

Canto, J. M. (1994). Psicología Social e Influencia. Estrategias de poder y procesos de cambio. Málaga: Algibe.

Candini, N. G. (1986). Las culturas populares en el capitalismo. Mexico DF: Nueva Imagen.

Comisión de Fomento Industrial, Comercial y Cooperativismo, (2008, January 18). Retrieved from: http:// www.legislaturaqro.gob.mx/index.php

El Financiero en línea, (2008, May 6). Retrieved from: http://fox.presidencia.gob.mx/buenasnoticias/?conte nido $=26536$ \&pagina $=47$

Hair, J. F, Anderson, R. L., Taham, W. \& Black, W. C. (2004). Análisis multivariante. Madrid: Pearson.

Hernández Sampieri, R., Fernández Collado, C. \& Baptista Lucio, O. (2003). Metodología de la Investigación. México: McGraw Hill.

Katz, D. Kahn, R. (1988). La psicología social de las organizaciones. Mexico D.F.: Trillas.

Moreno F., J. M. (1999). Psicología Social. Madrid: Mc Graw Hill.

Novelo, V. (1996). Artesanos, Artesanias y Arte Popular de México. Spain: Consejo Nacional para la Cultura y las Artes.

Peñaloza, P. M. (1982). Arte Popular de México. La creatividad artistica del pueblo mexicano a través de los tiempos. Mexico D.F.: Panorama.

Rodrígues, A. Assmar, E. \& Jablonski, B. (2002). Psicología social. México D.F.: Trillas.

Hernández, R., R., Fernández, C., \& Baptista, P. (2003). Metodología de la investigación. México D.F.: McGraw Hill.

Secretaría de Turismo, (2008 February 23). Retrieved from: http://turismo.edomex.gob.mx/turismo/artesanias.htm

Summers, G. (1986). Medicion de Actitudes. Mexico D.F.: Trillas.

Worchel, S., Cooper, J., Goethals, G. R. \& Olson, J. M. (2003). Psicología social. Madrid: Thompson.

Fecha de recepción: Junio 2010 Fecha de publicación: Diciembre 2010 